профессор

Голицынского

пограничного института, доктор

юридических наук

полковник Красинский В.В.

Professor of Golitsyno Military

Institute, doctor of law, colonel

Krasinsky Vladislav

Источник опубликования: Красинский $\quad$ B.B. Конституционно-правовое регулирование защиты государственного суверенитета в зарубежных странах // Современное право. 2016. № 3. С. 122-129.

\title{
Конституционно-правовое \\ регулирование \\ защиты государственного суверенитета в зарубежных странах
}

Аннотация: В статье анализируются конституционно-правовые аспекты защиты государственного суверенитета.

Ключевые слова: государственный суверенитет, защита государственного суверенитета, угрозы государственному суверенитету, конституционно-правовое регулирование, территория государства, особые правовые режимы, чрезвычайное положение, военное положение.

Annotation: The article analyses the constitutional aspects of protection of state sovereignty (national sovereignty).

Keywords: state sovereignty (national sovereignty), state sovereignty protection, threats to state sovereignty, constitutional-legal regulation, the territory of the state, special legal regimes, state of emergency, martial law.

Защита суверенитета любого государства нуждается в необходимом правовом обеспечении, и прежде всего, со стороны ведущей отрасли национальной системы права - конституционного права. Именно конституционно-правовые принципы лежат в основе разработки, осуществления и совершенствования государственной политики в сфере защиты государственного суверенитета, являются базовыми началами для подготовки необходимых концептуальных документов и правовых актов.

Многие зарубежные государства в ходе государственного строительства и конституционно-правового развития сталкивались с реализацией угроз конституционному строю, попытками целенаправленного ослабления своего суверенитета со стороны враждебных государств и военно-политических блоков, посягательствами на территориальную 
целостность и актами агрессии. Для нейтрализации возникающих угроз и антигосударственных сценариев задействовались разнообразные механизмы государственной защиты и применялись соответствующие экономические, политические, дипломатические, правовые и иные меры. Наиболее эффективные и долгосрочные механизмы защиты государственной независимости, конституционного строя и территориальной целостности получили закрепление на конституционном уровне.

В настоящее время проблема защиты государственного суверенитета с особой остротой встает перед политическим руководством Российской Федерации, стремящимся проводить самостоятельную внешнюю и внутреннюю политику. Для смены политического курса противниками России используются разнообразные средства: от экономических санкций и бойкотирования российских международных инициатив до убийства наших военнослужащих.

В связи с настойчивыми попытками «изолировать» Россию, продолжающимся экономическим давлением, экспансионистскими целями блока НАТО изучение зарубежного опыта конституционно-правового регулирования защиты государственного суверенитета представляется актуальным.

Рассмотрение вопросов защиты суверенитета предполагает изучение конституционно-правовой регламентации характеристик государственного суверенитета в ракурсе форм государства, территориального устройства, компетенции уполномоченных государственных органов и специальных правовых режимов. Проведем анализ конституционно-правового материала и выделим соответствующие тематические блоки.

Идеи государственного суверенитета в конституциях зарубежных стран нашли свое воплощение в нескольких вариациях:

- в характеристике форм государства;

- в положениях о территории государства; 
- в положениях о защите государственного суверенитета в различных сферах общественной жизни и полномочиях специальных государственных институтов (главы государства, правительства, парламента, Вооруженных Сил) по защите государственного суверенитета.

Значительная часть зарубежных стран провозгласила себя свободными, независимыми и суверенными государствами (ст. 1 Конституции Социалистической Республики Вьетнам, ст.1 Конституции Республики Индонезия, ст. 6 Конституции Республики Никарагуа, ст. 1 Политической конституции Боливии, ст. 1 Конституции Боливарианской Республики Венесуэла, ст. 43 Конституции Республики Перу, ст. 40 Конституции Мексиканских Соединенных Штатов).

При характеристике форм государства в конституциях большинства зарубежных стран указывается на принадлежность суверенной власти народу (ч.1 ст. 2 Конституции КНР, ч.2 ст.1 Конституции Республики Корея, ст.1 Конституции Японии, ст. 2 Конституции Социалистической Республики Вьетнам (далее - СРВ), ч.2 ст.1 Конституции Республики Индонезии, ст. 39 Конституции Мексиканских Соединенных Штатов, ст.2 Конституции Республики Никарагуа, ст.2 Политической Конституции Боливии, ст. 45 Конституции Республики Перу, ст. 5 Политической Конституции Республики Чили и др.). В некоторых Основных законах выделяются свойства государственного суверенитета (например, в ст. 2 Политической Конституции Боливии закреплены неотчуждаемость и неограниченность суверенитета, в ст. 13 Конституции Боливарианской Республики Венесуэла неограниченность суверенитета, в Переходных положениях Конституции Аргентинской Республики - законность суверенитета). Вместе с тем, в зарубежном законодательстве отмечается терминологическое смешение государственного, народного и национального суверенитета: во многих случаях данные понятия используются как синонимы.

Как известно, государственный суверенитет существует и распространяется на определенной территории. В конституционно-правовой 
доктрине территориальное верховенство выступает основным элементом государственного суверенитета. Не случайно одним из направлений реализации потенциала государства является всестороннее развитие и надежная защита национальной территории. В связи с этим в Основных законах зарубежных стран могут быть главы о национальных территориях и дан их перечень. Так, в ст.11 главы 1 Конституции Боливарианской Республики Венесуэла закреплено, что «Суверенитет Республики распространяется на континентальное и островное пространство, озера и реки, территориальное море, внутренние воды, исторически и жизненно необходимые и включающие береговые линии, установленные Республикой; поверхность почвы и все находящееся под ней; воздушное континентальное пространство, прибрежное и морское, а также ресурсы, находящиеся в них, включая и возможные месторождения, в том числе и мигрирующие воды, производимые ими продукты и их неприкосновенные компоненты, которые по природным причинам могут там оказаться. Прибрежное пространство Республики включает в себя архипелаг Лос-Монхес, архипелаг Лас-Авес, архипелаг Лос-Рокес, архипелаг Ла-Орчила, остров Ла-Тортуга, остров ЛаБланкилла, архипелаг Лос-Эрманос, острова Маргарита, Кубагуа и Коче, архипелаг Лос-Театигос, остров де Патос и остров де Авес и, кроме того, острова, скалы и отмели, расположенные или выступающие на поверхности территориального моря, которое покрывает континентальную платформу или находится в границах исключительной экономической зоны. Над пространством, образованным примыкающей морской зоной, континентальной платформой и исключительной экономической зоной, Республика осуществляет суверенные права и юрисдикцию в порядке, определяемом нормами международного права и национальным законодательством. Республика осуществляет свои права в космическом пространстве и в тех зонах, которые являются или могут являться общим 
достоянием всего человечества в порядке, определяемом международными договорами и национальным законодательством» ${ }^{1}$.

В ряде случаев в конституциях провозглашена цель восстановления территориальной целостности и подтверждение суверенитета над спорными территориями. В ч. 3 ст.66 Конституции Республики Корея сформулирована обязанность Президента Кореи «добиваться мирного объединения Родины» ${ }^{2}$ В Переходных положениях Конституции Аргентинской Республики указано: «Аргентинская нация подтверждает свой законный и безусловный суверенитет над Мальвинскими островами, Южной Джорджией и Южным Сандвичем и прилегающими водными и островными пространствами, являющимися неотъемлемой частью государственной территории. Возвращение указанных территорий и осуществление суверенитета над ними в полном объеме при уважительном отношении к образу жизни населяющих их жителей и с соблюдением принципов международного права составляют постоянную и неотчуждаемую от аргентинского народа цель».

Следует иметь в виду, что вопросы территории и установления границ государств традиционно регулируются не только конституционным законодательством, но и общепризнанными нормами и принципами международного права. В этой связи большую ценность представляет практика Международного Суда ООН, в результате которой Суд ООН выявил признаки осуществления государственного суверенитета на спорных территориях, сформулировал международные принципы установления границ и обстоятельства, обеспечивающие справедливую делимитацию․

1 Конституции государств Америки / Под ред. Т.Я. Хабриевой.Т.3. Южная Америка. М.: Институт законодательства и сравнительного правоведения при Правительстве Российской Федерации, 2006. С. 311.

${ }^{2}$ Конституции государств Азии / Под ред. Т.Я. Хабриевой. Т.3. Дальний Восток. М.: Институт законодательства и сравнительного правоведения при Правительстве Российской Федерации: Норма, 2010. С. 996.

${ }^{3}$ См. Решения Международного Суда ООН от 17 ноября 1953 г. «Дело об островах Менкье и Экрихос», от 20 июня 1959 г. «Дело, касающееся суверенитета над некоторыми приграничными землями», от 20 февраля 1969 г. «Дела о континентальном шельфе Северного моря», Консультативное заключение от 16 октября 1975 г. «Западная Сахара», от 20 января 1982 г. «Дело о делимитации морской границы в районе залива Мэн», от 3 
Так, в делах от 17 ноября 1953 г. об островах Менкье и Экрихос, от 20 июня 1959 г. о суверенитете над некоторыми приграничными землями, в консультативном заключении от 16 октября 1975 г. о Западной Сахаре Суд признал, что осуществление в течение длительного времени государственно властных функций является проявлением государственного суверенитета, весомым и достаточным поводом суверенной принадлежности территории.

В решении по делам о континентальном шельфе Северного моря от 20 февраля 1969 г. (делимитация границ континентального шельфа между ФРГ и Данией, с одной стороны, и между ФРГ и Нидерландами - с другой) Международный Суд ООН указал на то, что «при делимитации необходимо действовать по соглашению, следуя принципам справедливости и принимая во внимание все обстоятельства, относящиеся к делу, и тем самым оставить каждой стороне в максимально возможной мере все те части континентального шельфа, которые образуют естественное продолжение ее территории, без вторжения в естественное продолжение сухопутной территории другой стороны; и что если в результате такой делимитации произойдет частичное совпадение территорий, они должны быть разделены между сторонами в согласованных пропорциях либо, в случае недостижения соглашения, поровну, если стороны не примут решения о режиме совместной юрисдикции, совместном пользовании или эксплуатации. При переговорах в число факторов, которые должны быть приняты во внимание, необходимо включить: общую конфигурацию побережья сторон, а также его особые или необычные признаки; известные или легко устанавливаемые характеристики физической и геологической структуры и природные ресурсы континентального шельфа; показатель разумного соответствия между размерами территорий континентального шельфа, принадлежащих каждому

июня 1985 г. «Дело о континентальном шельфе между Ливийской Арабской Джамахирией и Мальтой» и др. 
государству, и длиной побережья этого государства, измеренной по общему направлению береговой линии» ${ }^{1}$.

В решении по делу о континентальном шельфе между Ливийской Арабской Джамахирией и Мальтой от 3 июня 1985 г. Суд учел положения Конвенции ООН 1982 г. по морскому праву и указал современные принципы международного права, применимые к делимитации континентального шельфа:

«Делимитация должна проводиться в соответствии с принципами справедливости с учетом всех обстоятельств. Район континентального шельфа, который должен быть определен как принадлежащий одной из сторон, не должен выходить за пределы 200 мильной береговой линии соответствующей стороны. При обеспечении справедливой делимитации должны учитываться: общая конфигурация побережья сторон, их противолежание и их взаимосвязь в общегеографическом контексте; различия в протяженности соответствующих береговых линий и расстояния между ними; необходимость избегать чрезмерного нарушения пропорциональности между размерами районов континентального шельфа, принадлежащих прибрежному государству, и длиной соответствующей части побережья, измеренной в общем направлении береговой линии»² .

Территориальное верховенство и максимальная степень национальной юрисдикции в пределах государственной территории могут иметь принципиальное значение. Не случайно в конституциях некоторых государств содержится прямой запрет на создание (размещение) на

1 Решение Международного Суда ООН от 20 февраля 1969 г. «Дела о континентальном шельфе Северного моря» / Краткое изложение решений, консультативных заключений и постановлений Международного Суда (1948-1991). НьюЙорк: ООН, 1993. С. 94.

2 Краткое изложение решений, консультативных заключений и постановлений Международного Суда (1948-1991). Нью-Йорк: ООН, 1993. С. 187. 
национальной территории военных баз иностранных государств (ст. 92 Конституции Республики Никарагуа) ${ }^{1}$.

Аналогичный запрет содержится в ст. 13 Конституции Боливарианской Республики Венесуэла: «Венесуэльское географическое пространство является зоной мира. На нем запрещено размещать иностранные военные базы или учреждения, которые имеют какие-либо цели военного характера или намереваются их иметь. ...Национальная территория не может быть отчуждена, сдана в аренду или передана каким-либо способом иностранным государствам и другим субъектам международного права» ${ }^{2}$.

В конституционной доктрине и соответствующих учредительных актах можно найти элементы защиты государственного суверенитета в социальноэкономической, политической и идеологической сферах общественной жизни.

Согласно ст. 99 Конституции Никарагуа «государство должно гарантировать существование и функционирование мелких и средних производителей». Данную социальную группу законодатель рассматривает как социальную базу экономического суверенитета и развития страны. В целях привлечения иностранного капитала в экономику «без ущерба национальному суверенитету государство обнародует закон об иностранных инвестициях» (ст. 100 Конституции Никарагуа) $)^{3}$.

Защита государственного суверенитета в политической сфере предполагает равноправные отношения с другими государствами, недопустимость вмешательства иностранных государств во внутренние дела, разрешение международных споров мирными средствами (Преамбула

1 Конституции государств Америки / Под ред. Т.Я. Хабриевой.Т.3. Южная Америка. М.: Институт законодательства и сравнительного правоведения при Правительстве Российской Федерации, 2006. С. 599.

2 Там же. С. 312.

${ }^{3}$ Конституции государств Америки / Под ред. Т.Я. Хабриевой. Т.1. Северная и Центральная Америка. М.: Институт законодательства и сравнительного правоведения при Правительстве Российской Федерации, 2006.С. 601. 
Конституции Японии, ст. 1 и 2 Конституции Республики Никарагуа, ст. 4 Конституции Федеративной Республики Бразилия).

В статьях 30 и 33 главы III Конституции СРВ содержатся положения, регламентирующие защиту государственного суверенитета в идеологической сфере: «Строго запрещается пропаганда реакционной и безнравственной идеологии и культуры... любая культурная и информационная деятельность, наносящая ущерб интересам государства и причиняющая вред личности, морали и достойному образу жизни вьетнамских граждан» ${ }^{1}$. Конституция Боливарианской Республики Венесуэла (ст. 15) возлагает на государство обязанность «обеспечивать национальную идентичность» ${ }^{2}$.

Особое внимание уделяется защите традиционных религиозных ценностей. Так, в ст. 3 Политической Конституции Боливии указано, что «государство признает и поддерживает римскую апостольскую католическую религию». В Преамбуле Конституции Республики Индонезии упоминается ключевая роль ислама в обретении индонезийским государством суверенитета.

В конституционных актах зарубежных стран содержится обязанность специально уполномоченных государственных органов или государства в целом защищать независимость, суверенитет и территориальную целостность государства. Ст. 15 Конституции Боливарианской Республики Венесуэла и ст. 44 Конституции Республики Перу возлагают эту обязанность на государство, ч. 2 ст. 66 Конституции Республики Корея - на Президента, а ст. 30 Конституции Республики Индонезия, 45 Конституции СРВ, ст. 92 Конституции Республики Никарагуа, ст. 208 Политической Конституции Боливии, ст. 217 Конституции Колумбии, ст. 165 Конституции Республики Перу - на Вооруженные силы).

${ }^{1}$ Конституции государств Азии / Под ред. Т.Я. Хабриевой. Т.3. Дальний Восток. М.: Институт законодательства и сравнительного правоведения при Правительстве Российской Федерации: Норма, 2010. С. 119.

2 Конституции государств Америки / Под ред. Т.Я. Хабриевой. Т.3. Южная Америка. М.: Институт законодательства и сравнительного правоведения при Правительстве Российской Федерации, 2006. С. 312. 
Комплекс полномочий по защите государственного суверенитета распределен между Главой государства, Правительством, Парламентом, Вооруженными силами, спецслужбами и судами ${ }^{1}$.

По общему правилу (независимо от формы правления) Глава государства выступает гарантом национального единства, обеспечивает стабильность и преемственность суверенной государственной власти. Реализуя полномочия в сфере обороны и безопасности, Глава государства объявляет состояние войны и мобилизацию, является Верховным Главнокомандующим и руководит Вооруженными силами при отражении иностранной агрессии или выполнении договорных обязательств. В целях защиты государственного суверенитета Глава государства вводит исключительные (чрезвычайные) режимы во всем государстве либо на части территории страны. Глава государства представляет страну на международной арене, подписывает международные соглашения, заключает мир.

В президентских и смешанных республиках Глава государства руководит высшим органом исполнительной власти, принимает конкретные меры в целях обеспечения правопорядка, общественной и государственной безопасности.

В парламентских республиках и монархиях перечень основных полномочий по защите государственного суверенитета сосредоточен у главы Правительства (фактическое руководство и контроль внутренней и внешней политики государства).

Парламент осуществляет законотворчество в целях защиты суверенитета государства, уполномочивает Главу государства использовать Вооруженные силы за пределами территории государства, разрешает транзитный проход или пребывание на территории государства военных кораблей, самолетов и техники иностранных государств, ратифицирует

\footnotetext{
${ }^{1}$ Как правило, роль и место спецслужб в защите государственного суверенитета в конституционных актах зарубежных стран не отражается. Данная деятельность регламентируется в законах и подзаконных актах.
} 
международные договоры ${ }^{1}$. Палаты Парламента могут проводить расследования деятельности спецслужб, в определенной мере контролировать строительство и реформирование Вооруженных сил.

Как уже отмечалось, в большинстве государств мира Вооруженные Силы и спецслужбы являются специализированными государственными организациями, предназначенными для защиты суверенитета, независимости и территориальной целостности. Исключением является Япония. После поражения во Второй мировой войне с подачи американских «юристов консультантов» в ст. 9 Конституции Японии 1947 г. был закреплен отказ государства от войны и создания сухопутных, морских и военно-воздушных сил: «Народ Японии в искреннем убеждении, что международный мир основан на справедливости и порядке, на вечные времена отказывается от войны как суверенного права нации, а также от угрозы или применения вооруженной силы как средства разрешения международных споров. ... Никогда впредь не будут создаваться сухопутные, морские и военновоздушные силы, равно как и другие средства ведения войны. Право на ведение государством войны не признается» ${ }^{2}$.

Уникальным институтом защиты государственного суверенитета являются суды. С одной стороны, судебные органы выступают на стороне государства (санкционируют проведение розыскных и специальных мероприятий, следственных действий, применение мер пресечения, наказание государственных преступников, запрет антигосударственных организаций). Специализированные органы конституционной юстиции разрешают дела о соответствии конституции и законам не вступивших в силу международных договоров, принимаемых государственными органами нормативных правовых актов, разрешают споры о компетенции.

${ }^{1}$ См. например, ст. 92 Конституции Республики Никарагуа, ст. 76 Конституции Мексиканских Соединенных Штатов.

${ }^{2}$ Конституции государств Азии / Под ред. Т.Я. Хабриевой. Т.3. Дальний Восток. М.: Институт законодательства и сравнительного правоведения при Правительстве Российской Федерации: Норма, 2010. С. 1023. 
С другой стороны, суды защищают законные интересы общества, права и свободы граждан: рассматривают жалобы о нарушениях законности в деятельности правоохранительных органов и спецслужб, о характере и объемах ограничений прав и свобод граждан в период действия исключительных (чрезвычайных) режимов, восстанавливают необоснованно нарушенные права и свободы, компенсируют гражданам и организациям нанесенный незаконными действиями и решениями должностных лиц ущерб.

Специальным элементом механизма защиты государственного суверенитета в зарубежных странах со сложной формой государственного устройства является федеральная интервенция. Данный институт направлен на обеспечение общественного порядка, реализации основополагающих прав и свобод, единства правового пространства государства, территориальной целостности, беспрепятственного осуществления государственной власти во всех субъектах Федерации.

Традиционным институтом защиты государственного суверенитета в зарубежных странах являются исключительные (чрезвычайные) правовые режимы. В Конституциях зарубежных стран закреплены типовые основания введения чрезвычайного положения (далее - ЧП).

По Конституции Республики Боливия (ст.111) режим ЧП объявляется «в случаях серьезной опасности для страны, вызванной внутренней угрозой или международной войной». Аналогичные причины предусмотрены в ст. 137 Конституции Федеративной Республики Бразилии: «серьезные волнения, имеющие последствия на национальном уровне; объявление состояния войны или принятие ответных мер на иностранную военную агрессию» ${ }^{1}$. В соответствии с ч.1 ст. 137 Конституции Республики Перу «ЧП вводится в случае нарушения мира или внутреннего порядка, катастроф или

1 Конституции государств Америки / Под ред. Т.Я. Хабриевой. Т.3. Южная Америка. М.: Институт законодательства и сравнительного правоведения при Правительстве Российской Федерации, 2006. С. 209. 
наступления чрезвычайных обстоятельств, представляющих угрозу жизни нации» ${ }^{1}$.

В ряде зарубежных стран закреплено несколько видов ЧП: чрезвычайное положение, чрезвычайное экономическое положение (Венесуэла), состояние внешнего или внутреннего конфликта (Венесуэла), военное положение (Колумбия).

В Чили система исключительных режимов представлена: состоянием мобилизации, состоянием ЧП, состоянием катастрофы, осадным положением, объявлением нации терпящей бедствие.

Как показывает анализ чрезвычайных конституционных положений, в случае дифференциации видов ЧП сроки введения специальных разновидностей исключительных режимов увязываются с основаниями их введения. Так, в Венесуэле ЧП может быть введено на срок до 30 дней в случае катастроф, стихийных бедствий и др. подобных событий, которые представляют серьезную угрозу безопасности нации, eе граждан. Чрезвычайное экономическое положение может быть провозглашено на срок до 60 дней в случае возникновения чрезвычайных экономических обстоятельств, которые серьезно воздействуют на экономическую жизнь нации. Состояние внешнего или внутреннего конфликта может быть объявлено на срок до 90 дней, если такой конфликт представляет серьезную угрозу безопасности нации, ее граждан.

В Венесуэле, в отличие от большинства государств мира, понятие ЧП сформулировано в тексте самой Конституции Боливарианской Республики. Согласно ст. 337 Конституции, ЧП квалифицируется как «такие обстоятельства социального, экономического, политического, природного или экологического характера, которые серьезно воздействуют на безопасность нации, на ее институты, граждан, при условии, что необходимые меры для ликвидации таких ситуаций являются

\footnotetext{
${ }^{1}$ Там же. C 824.
} 
недостаточными» ${ }^{1}$. Представляется, что подобная регламентация вызвана желанием законодателя исключить возможность избирательного введения ЧП для установления авторитарных режимов, расширения компетенции органов власти и управления, несудебного преследования представителей оппозиционных сил.

Распространенными конституционно-правовыми гарантиями недопустимости противоправного использования исключительных режимов под предлогом защиты государственного суверенитета выступают:

- предельные сроки введения подобных режимов и ограничительных мер (Чили - 15 дней; Бразилия - 30 дней; Венесуэла - 30 дней; Перу - 70 дней; Боливия - 90 дней; Колумбия - 90 дней);

- парламентский контроль (необходимость получения разрешений парламента на введение или продление чрезвычайных режимов; представление отчета о причинах введения ЧП и принятых мерах; возможность проведения парламентских расследований);

- невозможность роспуска парламента в период ЧП.

Одним из звеньев, связующих конституционно-правовую теорию и практику защиты государственного суверенитета, является доктрина пределов государственного суверенитета, закрепленная в некоторых конституциях ${ }^{2}$.

Анализ конституционных актов зарубежных стран позволяет вычленить доктринально-нормативное понимание пределов государственного суверенитета, которое включает несколько элементов.

1. Пределы государственного суверенитета устанавливаются Конституцией и законами в интересах граждан, общества и государства.

1 Конституции государств Америки / Под ред. Т.Я. Хабриевой. Т.3. Южная Америка. М.: Институт законодательства и сравнительного правоведения при Правительстве Российской Федерации, 2006. С. 401.

2 Политико-правовые взгляды ведущих ученых и юристов-конституционалистов на природу, содержание и свойства государственного суверенитета с течением времени в той или иной мере нашли свое выражение в конституционной доктрине пределов государственного суверенитета. 
Управляя общественными делами, государство не вправе руководствоваться только своими интересами. Государственная власть должна осуществляться в интересах общества и граждан и основываться на доверии населения (ст. 2 Конституции СРВ, Преамбула Конституции Японии).

2. Внутренние пределы государственного суверенитета неразрывно связаны с основополагающими правами и свободами человека. Произвольное ограничение государством основополагающих прав и свобод недопустимо. Государственные органы, общественные объединения и должностные лица обязаны уважать и обеспечивать реализацию основополагающих прав и свобод (ст. 5 Политической Конституции Республики Чили, ст. 11 Конституции Японии).

3. Внешние пределы государственного суверенитета определяются международной правосубъектностью государства.

4. Ограничение полноты и мощи государственной власти обеспечивается конституционными гарантиями (разделение властей; ответственность должностных лиц разных уровней за присвоение властных полномочий, восстания и мятежи; невозможность неконституционного порядка изменения или отмены Основного Закона и др.) ${ }^{1}$. Законодатели некоторых стран в качестве дополнительной конституционно-правовой гарантии защиты государственного суверенитета от узурпации права его осуществления отдельными лицами или группировками, недопущения неконституционных способов изменения или отмены Конституции предоставили народу право не подчиняться действиям и решениям лиц, пришедшим к власти в результате антигосударственных посягательств (восстаний, мятежей и др.), а также изменить форму правления в целях восстановления конституционного правопорядка и осуществления суверенитета в соответствии с Конституцией.

1 См. ст. 2 Политической Конституции Республики Боливии, ст.ст. 45, 46 Конституции Республики Перу, ст. 127 Конституции Республики Аргентины, ст. 85 Конституции Федеративной Республики Бразилия, ст. 333 Конституции Боливарианской Республики Венесуэла. 
Так, ст. 36 Конституции Аргентинской Республики предусмотрено право граждан противостоять лицам, осуществившим силовые акты против конституционного порядка и демократической системы ${ }^{1}$. В ст.39 Конституции Мексиканских Соединенных Штатов отмечается, что «народ в любое время имеет неотъемлемое право сменить и изменить форму правления» ${ }^{2}$. В ст. 46 Конституции Республики Перу закреплено право гражданского населения на восстание в защиту конституционного строя 3 .

Подводя итоги анализу конституционно-правовых норм, регулирующих защиту государственного суверенитета за рубежом, необходимо отметить наличие в конституциях иностранных государств специальных разделов или глав, посвященных защите государства и конституционного порядка (Конституция Боливарианской Республики Венесуэла, Конституция Республики Перу, Конституция Федеративной Республики Бразилия).

Полномочия по защите государственного суверенитета традиционно распределены между Главой государства, Правительством, Парламентом, Вооруженными силами, спецслужбами и судами. Особенности правосубъектности указанных институтов и реальный объем их полномочий по защите государственного суверенитета зависят от формы правления, государственного устройств, характера политического режима и конкретной общественно-политической ситуации.

Для государств со сложной формой государственного устройства специальным элементом механизма защиты государственного суверенитета может являться т.н. федеральная интервенция.

1 Конституции государств Америки / Под ред. Т.Я. Хабриевой. Т.3. Южная Америка. М.: Институт законодательства и сравнительного правоведения при Правительстве Российской Федерации, 2006. С.21.

${ }^{2}$ Конституции государств Америки / Под ред. Т.Я. Хабриевой. Т.1. Северная и Центральная Америка. М.: Институт законодательства и сравнительного правоведения при Правительстве Российской Федерации, 2006. С. 489.

3 Конституции государств Америки / Под ред. Т.Я. Хабриевой. Т.3. Южная Америка. М.: Институт законодательства и сравнительного правоведения при Правительстве Российской Федерации, 2006. С. 800. 
Распространенным правовым инструментом защиты государственного суверенитета в зарубежных странах выступают исключительные (чрезвычайные) правовые режимы.

Как представляется, проведенный в данной статье анализ зарубежного опыта конституционно-правового регулирования защиты государственного суверенитета позволяет выделить наиболее эффективные общие подходы к защите государственного суверенитета, критически оценить положение дел в сфере противодействия антигосударственной деятельности и обеспечения независимости государственной власти, определить нормативные решения, подходящие для российской правовой системы, и оптимизировать национальные правовые механизмы защиты государственного суверенитета. 